\title{
Vital Signs Reference Range Indicator
}

National Cancer Institute

\section{Source}

National Cancer Institute. Vital Signs Reference Range Indicator. NCI Thesaurus. Code C83459.

An indication that vital signs data lies within specified parameters. 